\title{
Zinc(II) Complexes Derived from Schiff Bases: Syntheses, Structures, and Biological Activity
}

\author{
Ling-Wei Xue, ${ }^{\star}$ Xu Fu, Gan-Qing Zhao and Qing-Bin Li
}

College of Chemistry and Chemical Engineering, Pingdingshan University, Pingdingshan Henan, 467000 P.R. China

*Corresponding author: E-mail: pdsuchemistry@163.com

Received: 01-06-2020

\begin{abstract}
Three new zinc(II) complexes, $\left[\mathrm{Zn}_{2} \mathrm{I}_{2}\left(\mathrm{~L}^{1}\right)_{2}\right](\mathbf{1}),\left[\mathrm{Zn}\left(\mathrm{HL}^{2}\right)_{2}(\mathrm{NCS})_{2}\right]$ (2), and $\left[\mathrm{ZnIL}^{3}\right]$ (3), where $\mathrm{L}^{1}$ is the anionic form of 2-[(6-methylpyridin-2-ylimino)methyl]phenol $\left(\mathrm{HL}^{1}\right), \mathrm{HL}^{2}$ is the zwitterionic form of 2-(cyclopropyliminomethyl)-5-fluorophenol $\left(\mathrm{HL}^{2}\right)$, and $\mathrm{L}^{3}$ is the anionic form of 5-bromo-2-[(3-morpholin-4-ylpropylimino)methyl] phenol $\left(\mathrm{HL}^{3}\right)$, have been prepared and characterized by elemental analyses, IR, UV and NMR spectra, and single crystal $\mathrm{X}$-ray crystallographic determination. Complex $\mathbf{1}$ is a dinuclear zinc complex, and complexes $\mathbf{2}$ and $\mathbf{3}$ are mononuclear zinc complexes. The $\mathrm{Zn}$ atoms in the complexes are in tetrahedral coordination. The effect of the complexes on the antimicrobial activity against Staphylococcus aureus, Escherichia coli, and Candida albicans were evaluated.
\end{abstract}

Keywords: Zinc complex, Schiff base, Crystal structure, Antimicrobial activity

\section{Introduction}

The rapid increasing interest in the synthesis and structural studies of Schiff bases is due to their bioactivity and coordination properties. ${ }^{1}$ Schiff bases are active against fungal, cancer, convulsant, oxidant and diuretic activities. ${ }^{2}$ Metal complexes of Schiff bases have attracted considerable attention due to their versatile biological activity, such as antifungal, antibacterial and antitumor. ${ }^{3}$ And, in general, the metal complexes have higher biological activities than the free Schiff bases. It has been shown that the Schiff base complexes derived from salicylaldehyde and its derivatives with primary amines, bearing the $\mathrm{N}_{2} \mathrm{O}, \mathrm{N}_{2} \mathrm{~S}, \mathrm{NO}_{2}$ or $\mathrm{NSO}$ donor sets, have potential antimicrobial activities. ${ }^{4} \mathrm{Zinc}$ is an important biological element, its complexes derived from Schiff bases have received particular attention due to their interesting antimicrobial potential. ${ }^{5}$ Recent research indicated that the halide and pseudohalide groups can severely increase the antimicrobial activities. ${ }^{6}$ Our research group has reported some metal complexes with effective antimi- crobial activities. ${ }^{7}$ In pursuit of new and efficient antimicrobial agents, in the present work, three new zinc(II) complexes, $\left[\mathrm{Zn}_{2} \mathrm{I}_{2}\left(\mathrm{~L}^{1}\right)_{2}\right](\mathbf{1}),\left[\mathrm{Zn}\left(\mathrm{HL}^{2}\right)_{2}(\mathrm{NCS})_{2}\right](\mathbf{2})$, and $\left[\mathrm{ZnIL}^{3}\right](\mathbf{3})$, where $\mathrm{L}^{1}$ is the anionic form of 2-[(6-methylpyridin-2-ylimino)methyl]phenol $\left(\mathrm{HL}^{1}\right), \mathrm{HL}^{2}$ is the zwitterionic form of 2-(cyclopropyliminomethyl)-5-fluorophenol $\left(\mathrm{HL}^{2}\right)$, and $\mathrm{L}^{3}$ is the anionic form of 5-bromo-2-[(3-morpholin-4-ylpropylimino)methyl]phenol $\left(\mathrm{HL}^{3}\right)$ (Scheme 1), are reported. To our knowledge, only two complexes with $\mathrm{HL}^{1,8}$ and no complexes with $\mathrm{HL}^{2}$ and

\section{Experimental}

\section{1. Material and Methods}

Salicylaldehyde, 4-fluorosalicylaldehyde, 4-bromosalicylaldehyde, 2-amino-6-methylpyridine, cyclopropylamine, and 3-morpholin-4-ylpropylamine were purchased from Fluka. Other reagents and solvents were analytical grade and used without further purification. Ele-<smiles>Cc1cccc(/N=C/c2ccccc2O)n1</smiles>

$\mathrm{HL}^{1}$<smiles>Oc1cc(F)ccc1/C=N/C1CC1</smiles>

$\mathrm{HL}^{2}$<smiles>Oc1cc(Br)ccc1C=NCCCN1CCOCC1</smiles>

$\begin{array}{ll}\mathrm{HL}^{3} & \mathrm{HL}^{3} \text { have been } \\ \text { reported so far. }\end{array}$

Scheme 1. The Schiff bases 
mental $(\mathrm{C}, \mathrm{H}$, and $\mathrm{N})$ analyses were made on a PerkinElmer Model 240B automatic analyser. Zinc analysis was carried out by EDTA titration. Infrared (IR) spectra were recorded on an IR-408 Shimadzu 568 spectrophotometer. UV-Vis spectra were recorded on a Lambda 900 spectrometer. X-ray diffraction was carried out on a Bruker SMART $1000 \mathrm{CCD}$ area diffractometer. ${ }^{1} \mathrm{H}$ and ${ }^{13} \mathrm{C}$ NMR spectra were recorded on a Bruker $300 \mathrm{MHz}$ spectrometer.

\section{2. Synthesis of the Ligands}

\section{2. 1. 2-[(6-Methylpyridin-2-ylimino)methyl] phenol $\left(\mathrm{HL}^{\mathbf{1}}\right)$}

Salicylaldehyde $(1.22 \mathrm{~g}, 0.01 \mathrm{~mol})$ and 2-amino-6-methylpyridine $(1.06 \mathrm{~g}, 0.01 \mathrm{~mol})$ were reacted in methanol $(50 \mathrm{~mL})$ for $30 \mathrm{~min}$ at $20^{\circ} \mathrm{C}$. The solvent was removed by distillation to give yellow product of $\mathrm{HL}^{1}$. Analysis Calcd. (\%) for $\mathrm{C}_{13} \mathrm{H}_{12} \mathrm{~N}_{2} \mathrm{O}$ : C 73.56, H 5.70, N 13.20. Found (\%): C 73.41, H 5.82, N 13.05. IR data $(\mathrm{KBr}$, $\left.\mathrm{cm}^{-1}\right): 1623(\mathrm{CH}=\mathrm{N})$. UV in acetonitrile $(\lambda, \varepsilon): 273 \mathrm{~nm}$, $1.03 \times 10^{4} \mathrm{~L} \mathrm{~mol}^{-1} \mathrm{~cm}^{-1} ; 350 \mathrm{~nm}, 2.77 \times 10^{3} \mathrm{~L} \mathrm{~mol}^{-1} \mathrm{~cm}^{-1}$. ${ }^{1} \mathrm{H}$ NMR (300 MHz, $d^{6}$-DMSO): $\delta 12.11(\mathrm{~s}, 1 \mathrm{H}, \mathrm{OH}), 8.63$ (s, $1 \mathrm{H}, \mathrm{CH}=\mathrm{N}), 7.68-7.64(\mathrm{~m}, 3 \mathrm{H}, \mathrm{ArH}$ and $\mathrm{PyH}), 7.46$ (t, $1 \mathrm{H}, \operatorname{Ar} H), 7.10(\mathrm{t}, 1 \mathrm{H}, \operatorname{Ar} H), 6.99(\mathrm{~d}, 1 \mathrm{H}, \operatorname{Ar} H), 6.81(\mathrm{~d}$, $1 \mathrm{H}, \mathrm{PyH}), 2.50\left(\mathrm{~s}, 3 \mathrm{H}, \mathrm{CH}_{3}\right) .{ }^{13} \mathrm{C}$ NMR $(126 \mathrm{MHz}, \mathrm{DMSO})$ $\delta 162.32,161.87,160.11,159.23,138.12,133.03,132.72$, $121.85,121.36,119.77,115.61,112.22,23.70$.

\section{2. 2. 2-(Cyclopropyliminomethyl)-5- fluorophenol $\left(\mathrm{HL}^{2}\right)$}

4-Fluorosalicylaldehyde $(1.40 \mathrm{~g}, 0.01 \mathrm{~mol})$ and cyclopropylamine $(0.57 \mathrm{~g}, 0.01 \mathrm{~mol})$ were reacted in methanol $(50 \mathrm{~mL})$ for $30 \mathrm{~min}$ at $20^{\circ} \mathrm{C}$. The solvent was removed by distillation to give yellow product of $\mathrm{HL}^{2}$. Analysis Calcd. (\%) for $\mathrm{C}_{10} \mathrm{H}_{10} \mathrm{FNO}$ : $\mathrm{C} 67.03, \mathrm{H}$ 5.62, $\mathrm{N}$ 7.82. Found (\%): C 67.16, H 5.54, N 7.96. IR data $\left(\mathrm{KBr}, \mathrm{cm}^{-1}\right): 1627$ $(\mathrm{CH}=\mathrm{N})$. UV in acetonitrile $(\lambda, \varepsilon): 233 \mathrm{~nm}, 1.51 \times 10^{4} \mathrm{~L}$ $\mathrm{mol}^{-1} \mathrm{~cm}^{-1} ; 265 \mathrm{~nm}, 8.38 \times 10^{3} \mathrm{~L} \mathrm{~mol}^{-1} \mathrm{~cm}^{-1} ; 346 \mathrm{~nm}, 5.10$ $\times 10^{3} \mathrm{~L} \mathrm{~mol}^{-1} \mathrm{~cm}^{-1} .{ }^{1} \mathrm{H}$ NMR $\left(300 \mathrm{MHz}, d^{6}\right.$-DMSO) $\delta$ $12.15(\mathrm{~s}, 1 \mathrm{H}, \mathrm{OH}), 8.67(\mathrm{~s}, 1 \mathrm{H}, \mathrm{CH}=\mathrm{N}), 7.61(\mathrm{~d}, 1 \mathrm{H}, \mathrm{Ar} H)$, $6.87(\mathrm{~d}, 1 \mathrm{H}, \operatorname{Ar} H), 6.43(\mathrm{~s}, 1 \mathrm{H}, \operatorname{Ar} H), 1.82(\mathrm{~m}, 1 \mathrm{H}, \mathrm{CH})$, $0.71\left(\mathrm{~m}, 2 \mathrm{H}, \mathrm{CH}_{2}\right), 0.43\left(\mathrm{~m}, 2 \mathrm{H}, \mathrm{CH}_{2}\right),{ }^{13} \mathrm{C}$ NMR $(126$ MHz, DMSO) $\delta 167.13,162.77,161.10,132.05,120.54$, $109.23,103.82,35.11,6.77$.

\section{2. 3. 5-Bromo-2-[(3-morpholin-4- ylpropylimino)methyl]phenol $\left(\mathrm{HL}^{3}\right)$}

4-Bromosalicylaldehyde (2.01 g, $0.01 \mathrm{~mol})$ and 3-morpholin-4-ylpropylamine $(1.44 \mathrm{~g}, 0.01 \mathrm{~mol})$ were reacted in methanol $(50 \mathrm{~mL})$ for $30 \mathrm{~min}$ at $20^{\circ} \mathrm{C}$. The solvent was removed by distillation to give yellow product of $\mathrm{HL}^{3}$. Analysis Calcd. (\%) for $\mathrm{C}_{14} \mathrm{H}_{19} \mathrm{BrN}_{2} \mathrm{O}_{2}$ : C 51.39, $\mathrm{H} 5.85, \mathrm{~N}$ 8.56. Found (\%): C 51.31, H 5.77, N 8.71. IR data ( $\mathrm{KBr}$, $\left.\mathrm{cm}^{-1}\right): 1633(\mathrm{CH}=\mathrm{N})$. UV in acetonitrile $(\lambda, \varepsilon): 228 \mathrm{~nm}$,
$1.36 \times 10^{4} \mathrm{~L} \mathrm{~mol}^{-1} \mathrm{~cm}^{-1} ; 274 \mathrm{~nm}, 6.73 \times 10^{3} \mathrm{~L} \mathrm{~mol}^{-1} \mathrm{~cm}^{-1}$; $335 \mathrm{~nm}, 3.35 \times 10^{3} \mathrm{~L} \mathrm{~mol}^{-1} \mathrm{~cm}^{-1}$. ${ }^{1} \mathrm{H}$ NMR $(300 \mathrm{MHz}$, $d^{6}$-DMSO): $\delta 11.78(\mathrm{~s}, 1 \mathrm{H}, \mathrm{OH}), 8.58(\mathrm{~s}, 1 \mathrm{H}, \mathrm{CH}=\mathrm{N}), 7.51$ (d, $1 \mathrm{H}, \operatorname{Ar} H), 7.47(\mathrm{~s}, 1 \mathrm{H}, \operatorname{ArH}), 7.11(\mathrm{~d}, 1 \mathrm{H}, \operatorname{ArH}), 3.68(\mathrm{t}$, $\left.2 \mathrm{H}, \mathrm{CH}_{2}\right), 3.60\left(\mathrm{q}, 4 \mathrm{H}, \mathrm{CH}_{2}\right), 2.43\left(\mathrm{t}, 2 \mathrm{H}, \mathrm{CH}_{2}\right), 2.27(\mathrm{q}, 4 \mathrm{H}$, $\left.\mathrm{CH}_{2}\right), 1.72\left(\mathrm{~m}, 2 \mathrm{H}, \mathrm{CH}_{2}\right) .{ }^{13} \mathrm{C}$ NMR (126 MHz, DMSO) $\delta$ $162.11,156.35,133.20,125.07,124.31,120.89,114.34$, 67.18, 62.83, 59.22, 54.71, 29.67.

\section{3. Synthesis of the Complexes}

\section{3. 1. $\left[\mathrm{Zn}_{2} \mathrm{I}_{2}\left(\mathrm{~L}^{1}\right)_{2}\right](1)$}

Then, a methanol solution $(20 \mathrm{~mL})$ of $\mathrm{ZnI}_{2}(0.319 \mathrm{~g}$, $1.0 \mathrm{mmol}$ ) was added to the methanol solution of $\mathrm{HL}^{1}$ $(0.212 \mathrm{~g}, 1.0 \mathrm{mmol})$. The mixture was stirred for $1 \mathrm{~h}$ at 20 ${ }^{\circ} \mathrm{C}$ to give a colorless solution. Colorless block-shaped single crystals suitable for X-ray diffraction were formed by slow evaporation of the solution in air for several days. The yield was 45\% (based on $\mathrm{HL}^{1}$ ). Analysis Calcd. (\%) for $\mathrm{C}_{26} \mathrm{H}_{22} \mathrm{I}_{2} \mathrm{~N}_{4} \mathrm{O}_{2} \mathrm{Zn}_{2}$ : C 38.69, H 2.75, N 6.94, Zn 16.20. Found (\%): C 38.82, H 2.63, N 6.85, Zn 16.37. IR data $\left(\mathrm{KBr}, \mathrm{cm}^{-1}\right): 1615(\mathrm{CH}=\mathrm{N})$. UV in acetonitrile $(\lambda, \varepsilon): 310$ $\mathrm{nm}, 3.13 \times 10^{3} \mathrm{~L} \mathrm{~mol}^{-1} \mathrm{~cm}^{-1} ; 410 \mathrm{~nm}, 2.32 \times 10^{3} \mathrm{~L} \mathrm{~mol}^{-1}$ $\mathrm{cm}^{-1} .{ }^{1} \mathrm{H}$ NMR $\left(300 \mathrm{MHz}, d^{6}\right.$-DMSO): $\delta 8.71(\mathrm{~s}, 1 \mathrm{H}$, $\mathrm{CH}=\mathrm{N}), 7.81-7.45(\mathrm{~m}, 4 \mathrm{H}, \mathrm{ArH}$ and $\mathrm{PyH}), 7.10(\mathrm{t}, 1 \mathrm{H}$, $\operatorname{ArH}), 6.92(\mathrm{~d}, 1 \mathrm{H}, \operatorname{Ar} H), 6.82(\mathrm{~d}, 1 \mathrm{H}, \mathrm{PyH}), 2.50(\mathrm{~s}, 3 \mathrm{H}$, $\mathrm{CH}_{3}$ ). ${ }^{13} \mathrm{C}$ NMR $(126 \mathrm{MHz}, \mathrm{DMSO}) \delta 163.41,162.02$, $161.05,159.33,138.17,132.92,132.65,121.82,121.71$, $120.14,115.66,112.31,23.70$.

\section{3. 2. $\left[\mathrm{Zn}\left(\mathrm{HL}^{2}\right)_{2}(\mathrm{NCS})_{2}\right](2)$}

A methanol solution $(20 \mathrm{~mL})$ of $\mathrm{Zn}\left(\mathrm{ClO}_{4}\right)_{2} \cdot 6 \mathrm{H}_{2} \mathrm{O}$ $(0.372 \mathrm{~g}, 1.0 \mathrm{mmol})$ and ammonium thiocyanate $(0.076 \mathrm{~g}$, $1.0 \mathrm{mmol}$ ) was added to the methanol solution of $\mathrm{HL}^{2}$ $(0.179 \mathrm{~g}, 1.0 \mathrm{mmol})$. The mixture was stirred for $1 \mathrm{~h}$ at 20 ${ }^{\circ} \mathrm{C}$ to give a colorless solution. Colorless block-shaped single crystals suitable for X-ray diffraction were formed by slow evaporation of the solution in air for several days. The yield was $37 \%$ (based on $\mathrm{HL}^{2}$ ). Analysis Calcd. (\%) for $\mathrm{C}_{22} \mathrm{H}_{20} \mathrm{~F}_{2} \mathrm{~N}_{4} \mathrm{O}_{2} \mathrm{~S}_{2} \mathrm{Zn}$ : C 48.94, H 3.73, N 10.38, Zn 12.11 . Found (\%): C 49.13, H 3.82, N 10.28, Zn 12.35. IR data $\left(\mathrm{KBr}, \mathrm{cm}^{-1}\right): 2073(\mathrm{NCS}), 1653(\mathrm{CH}=\mathrm{NH})$. UV in acetonitrile $(\lambda, \varepsilon): 270 \mathrm{~nm}, 3.56 \times 10^{3} \mathrm{~L} \mathrm{~mol}^{-1} \mathrm{~cm}^{-1} ; 305 \mathrm{~nm}, 1.91$ $\times 10^{3} \mathrm{~L} \mathrm{~mol}^{-1} \mathrm{~cm}^{-1} ; 350 \mathrm{~nm}, 8.33 \times 10^{2} \mathrm{~L} \mathrm{~mol}^{-1} \mathrm{~cm}^{-1} ; 397$ $\mathrm{nm}, 2.06 \times 10^{2} \mathrm{~L} \mathrm{~mol}^{-1} \mathrm{~cm}^{-1}$. ${ }^{1} \mathrm{H}$ NMR $\left(300 \mathrm{MHz}, d^{6}-\mathrm{DM}-\right.$ SO): $\delta 10.82(\mathrm{~s}, 1 \mathrm{H}, \mathrm{NH}), 8.75(\mathrm{~s}, 1 \mathrm{H}, \mathrm{CH}=\mathrm{N}), 7.61(\mathrm{~d}, 1 \mathrm{H}$, $\operatorname{ArH}), 6.87$ (d, $1 \mathrm{H}, \operatorname{ArH}), 6.46(\mathrm{~s}, 1 \mathrm{H}, \mathrm{ArH}), 1.83(\mathrm{~m}, 1 \mathrm{H}$, $\mathrm{CH}), 0.71\left(\mathrm{~m}, 2 \mathrm{H}, \mathrm{CH}_{2}\right), 0.43\left(\mathrm{~m}, 2 \mathrm{H}, \mathrm{CH}_{2}\right) .{ }^{13} \mathrm{C} \mathrm{NMR}(126$ $\mathrm{MHz}, \mathrm{DMSO}) \delta 167.35,162.45,163.27,135.86,132.13$, $119.71,109.43,104.51,34.78,6.77$.

\section{3. 3. $\left[\mathrm{ZnIL}^{3}\right](3)$}

A methanol solution $(20 \mathrm{~mL})$ of $\mathrm{ZnI}_{2}(0.319 \mathrm{~g}, 1.0$ $\mathrm{mmol})$ was added to the methanol solution of $\mathrm{HL}^{3}(0.326 \mathrm{~g}$, 
$1.0 \mathrm{mmol}$ ). The mixture was stirred for $1 \mathrm{~h}$ at $20^{\circ} \mathrm{C}$ to give a colorless solution. Colorless block-shaped single crystals suitable for X-ray diffraction were formed by slow evaporation of the solution in air for several days. The yield was 54\% (based on $\mathrm{HL}^{3}$ ). Analysis Calcd. (\%) for $\mathrm{C}_{14} \mathrm{H}_{18} \mathrm{BrIN}_{2} \mathrm{O}_{2} \mathrm{Zn}$ : C 32.43, H 3.50, N 5.40, Zn 12.61. Found (\%): C 32.27, H 3.63, N 5.45, Zn 12.82. IR data $\left(\mathrm{KBr}, \mathrm{cm}^{-1}\right): 1637(\mathrm{CH}=\mathrm{N})$. UV in acetonitrile $(\lambda, \varepsilon): 225 \mathrm{~nm}, 3.78 \times 10^{3} \mathrm{~L} \mathrm{~mol}^{-1} \mathrm{~cm}^{-1} ; 242 \mathrm{~nm}, 3.11 \times$ $10^{3} \mathrm{~L} \mathrm{~mol}^{-1} \mathrm{~cm}^{-1} ; 278 \mathrm{~nm}, 1.85 \times 10^{3} \mathrm{~L} \mathrm{~mol}^{-1} \mathrm{~cm}^{-1} ; 357 \mathrm{~nm}$, $9.28 \times 10^{2} \mathrm{~L} \mathrm{~mol}^{-1} \mathrm{~cm}^{-1} .{ }^{1} \mathrm{H}$ NMR $\left(300 \mathrm{MHz}, d^{6}\right.$-DMSO): $\delta$ $8.67(\mathrm{~s}, 1 \mathrm{H}, \mathrm{CH}=\mathrm{N}), 7.50(\mathrm{~d}, 1 \mathrm{H}, \operatorname{Ar} H), 7.45(\mathrm{~s}, 1 \mathrm{H}, \operatorname{Ar} H)$, $7.11(\mathrm{~d}, 1 \mathrm{H}, \mathrm{ArH}), 3.67\left(\mathrm{t}, 2 \mathrm{H}, \mathrm{CH}_{2}\right), 3.62\left(\mathrm{q}, 4 \mathrm{H}, \mathrm{CH}_{2}\right), 2.37$ $\left(\mathrm{t}, 2 \mathrm{H}, \mathrm{CH}_{2}\right), 2.27\left(\mathrm{q}, 4 \mathrm{H}, \mathrm{CH}_{2}\right), 1.73\left(\mathrm{~m}, 2 \mathrm{H}, \mathrm{CH}_{2}\right) .{ }^{13} \mathrm{C} \mathrm{NMR}$ (126 MHz, DMSO) $\delta 164.32,158.11,132.87,125.12,124.26$, $121.81,114.51,67.25,63.02,59.38,54.66,29.71$.

\section{4. X-Ray Diffraction}

Data were collected from selected crystals mounted on glass fibres. The data were collected with $\mathrm{MoK}_{\alpha}$ radiation $(0.71073 \AA$ ) at $298(2) \mathrm{K}$ with a Bruker SMART 1000 $\mathrm{CCD}$ area diffractometer. The data for the complexes were processed with SAINT ${ }^{9}$ and corrected for absorption using SADABS. ${ }^{10}$ Multi-scan absorption corrections were applied with $\psi$-scans. ${ }^{11}$ The structures were solved by direct method using SHELXS-97 and refined by full-matrix least-squares techniques on $F^{2}$ using anisotropic displacement parameters. ${ }^{12}$ The imino $\mathrm{H}$ atom in complex 2 was located form a difference Fourier map and refined with $\mathrm{N}-\mathrm{H}$ distance of 0.90(1) $\AA$. All other hydrogen atoms were placed at the calculated positions. Idealized $\mathrm{H}$ atoms were refined with isotropic displacement parameters set to 1.2 (1.5 for methyl groups) times the equivalent isotropic $U$ values of the parent carbon atoms. The crystallographic data for the complexes are listed Table 1.

Supplementary material has been deposited with the Cambridge Crystallographic Data Centre (nos. 1448092 (1), 1975485 (2), 1975486 (3)); deposit@ccdc.cam.ac.uk or http://www.ccdc.cam.ac.uk).

\section{5. Antimicrobial Assay}

Qualitative determination of antimicrobial activity was done using the disk diffusion method. ${ }^{13}$ The antibac-

Table 1. Crystallographic data and experimental details for the complexes

\begin{tabular}{|c|c|c|c|}
\hline & 1 & 2 & 3 \\
\hline Molecular formula & $\mathrm{C}_{26} \mathrm{H}_{22} \mathrm{I}_{2} \mathrm{~N}_{4} \mathrm{O}_{2} \mathrm{Zn}_{2}$ & $\mathrm{C}_{22} \mathrm{H}_{20} \mathrm{~F}_{2} \mathrm{~N}_{4} \mathrm{O}_{2} \mathrm{~S}_{2} \mathrm{Zn}$ & $\mathrm{C}_{14} \mathrm{H}_{18} \mathrm{BrIN}_{2} \mathrm{O}_{2} \mathrm{Zn}$ \\
\hline Formula weight & 807.02 & 539.91 & 518.48 \\
\hline Crystal size, $\mathrm{mm}$ & $0.27 \times 0.26 \times 0.26$ & $0.23 \times 0.22 \times 0.21$ & $0.17 \times 0.15 \times 0.15$ \\
\hline Radiation $(\lambda, \AA)$ & $\operatorname{Mo} K_{\alpha}(0.71073)$ & $\operatorname{MoK}_{\alpha}(0.71073)$ & $\operatorname{MoK}_{\alpha}(0.71073)$ \\
\hline Crystal system & Triclinic & Monoclinic & Monoclinic \\
\hline Space group & $P-1$ & $P 2 / c$ & $P 2_{1} / c$ \\
\hline \multicolumn{4}{|l|}{ Unit cell dimensions: } \\
\hline$a, \AA$ & $8.056(2)$ & $10.920(1)$ & $15.065(2)$ \\
\hline$b, \AA$ & $8.659(2)$ & $7.021(1)$ & $9.023(1)$ \\
\hline$c, \AA$ & $11.034(2)$ & $16.122(1)$ & $12.860(1)$ \\
\hline$\alpha,{ }^{\circ}$ & $78.264(2)$ & 90 & 90 \\
\hline$\beta,{ }^{\circ}$ & $74.640(2)$ & $97.347(1)$ & $105.203(1)$ \\
\hline$\gamma,{ }^{\circ}$ & $69.431(2)$ & 90 & 90 \\
\hline$V, \AA^{3}$ & $689.7(3)$ & $1225.9(3)$ & $1687.0(3)$ \\
\hline$Z$ & 1 & 2 & 4 \\
\hline$\rho_{\text {calcd }}, \mathrm{g} \mathrm{cm}^{-3}$ & 1.943 & 1.463 & 2.041 \\
\hline$F(000)$ & 388 & 552 & 1000 \\
\hline$T_{\min }, T_{\max }$ & $0.4109,0.4222$ & $0.7678,0.7847$ & $0.4463,0.4840$ \\
\hline Absorption coefficient, $\mathrm{mm}^{-1}$ & 4.007 & 1.213 & 5.659 \\
\hline$\theta$ Range for data collection, ${ }^{\circ}$ & $1.93-25.49$ & $1.88-25.50$ & $1.40-25.50$ \\
\hline Reflections collected & 4159 & 6294 & 33117 \\
\hline Independent reflections $\left(R_{\text {int }}\right)$ & $2571(0.0315)$ & $2287(0.0495)$ & $3135(0.0809)$ \\
\hline Reflections with $I>2 \sigma(I)$ & 1832 & 1473 & 2431 \\
\hline Data/parameters & $2571 / 164$ & $2287 / 154$ & $3135 / 190$ \\
\hline Restraints & 0 & 1 & 0 \\
\hline Goodness-of-fit on $F^{2}$ & 1.040 & 1.024 & 1.058 \\
\hline Final $R$ indices $(I>2 \sigma(I))$ & $\begin{array}{l}R_{1}=0.0457 \\
w R_{2}=0.0878\end{array}$ & $\begin{array}{l}R_{1}=0.0688 \\
w R_{2}=0.1835\end{array}$ & $\begin{array}{l}R_{1}=0.0404 \\
w R_{2}=0.0936\end{array}$ \\
\hline$R$ indices (all data) & $\begin{array}{l}R_{1}=0.0736 \\
w R_{2}=0.1026\end{array}$ & $\begin{array}{l}R_{1}=0.1057 \\
w R_{2}=0.2073\end{array}$ & $\begin{array}{l}R_{1}=0.0605 \\
w R_{2}=0.1081\end{array}$ \\
\hline$\Delta \rho_{\max }, \Delta \rho_{\min }, e \AA^{-3}$ & $1.38,-0.55$ & $1.47,-0.39$ & $0.84,-0.64$ \\
\hline
\end{tabular}


terial activity was tested against B. subtilis, E. coli, P. fluorescence and $S$. aureus using MH medium (Mueller-Hinton medium). The MICs (minimum inhibitory concentrations) of the test compounds were determined by a colorimetric method using the dye MTT [3-(4,5-dimethylthiazol-2-yl)-2,5-diphenyltetrazolium bromide]. A stock solution of the synthesized compound $\left(50 \mu \mathrm{g} \mathrm{mL} \mathrm{m}^{-1}\right)$ in DMSO was prepared and quantities of the test compounds were incorporated in specified quantity of sterilized liquid MH medium. A specified quantity of the medium containing the compound was poured into micro-titration plates. A suspension of the microorganism was prepared to contain approximately $10^{5} \mathrm{cfu} \mathrm{mL}^{-1}$ and applied to micro-titration plates with serially diluted compounds in DMSO to be tested and incubated at $37^{\circ} \mathrm{C}$ for $24 \mathrm{~h}$. After the MICs were visually determined on each of the micro-titration plates, $50 \mu \mathrm{L}$ of PBS containing $2 \mathrm{mg}$ of MTT per millilitre was added to each well. Incubation was continued at room temperature for $4-5 \mathrm{~h}$. The content of each well was removed and $100 \mu \mathrm{L}$ of isopropanol containing hydrochloric acid was added to extract the dye. After $12 \mathrm{~h}$ of incubation at room temperature, the optical density (OD) was measured with a micro-plate reader at $550 \mathrm{~nm}$.

\section{Results and Discussion}

\section{1. Chemistry}

The Schiff bases were readily prepared by the reaction of equimolar quantities of aldehyde and amines in methanol, which were used directly for the preparation of the zinc complexes at ambient temperature. The zinc complexes are stable at room temperature in the solid state and soluble in common organic solvents, such as methanol, ethanol, chloroform, and acetonitrile. The results of the elemental analyses are in accord with the composition suggested for the complexes.

\section{2. IR and Electronic Spectra}

The IR spectra of the complexes were analyzed and compared with those of their free Schiff bases. The intense absorption bands at 1623,1627 and $1633 \mathrm{~cm}^{-1}$ in the spectra of the Schiff bases $\mathrm{HL}^{1}, \mathrm{HL}^{2}$ and $\mathrm{HL}^{3}$, respectively, can be assigned to the $\mathrm{C}=\mathrm{N}$ stretching. In the complexes, these bands are shifted to 1615,1653 and $1637 \mathrm{~cm}^{-1}$ upon complexation with the zinc atoms, which can be attributed to the coordination of the imine nitrogen to the metal centre. ${ }^{14}$ The absorption of this band for complex $\mathbf{2}$ is located at higher wavelength than complexes $\mathbf{2}$ and $\mathbf{3}$, which is due to the protonation of the imino group. The typical absorption at $2073 \mathrm{~cm}^{-1}$ in the spectrum of complex 2 is assigned to the vibration of the NCS ligand. ${ }^{15}$

UV-Vis spectra of the free Schiff bases and the complexes were recorded in HPLC grade acetonitrile solution. The spectra of the Schiff bases exhibit bands at 220-280 $\mathrm{nm}$ and $330-360 \mathrm{~nm}$ attributed to $\pi \rightarrow \pi^{*}$ and $\mathrm{n} \rightarrow \pi^{*}$ transitions. In the spectra of the complexes the charge transfer bands at 220-280 nm remain intact, in agreement with the $\pi \rightarrow \pi^{*}$ transitions of the Schiff base ligands. The remaining bands at $350-410 \mathrm{~nm}$ in the spectra of the complexes are assigned to the metal to ligand charge transfer (MLCT) transition. ${ }^{16}$

\section{3. NMR Spectra}

The ${ }^{1} \mathrm{H}$ NMR spectra of the Schiff bases exhibit $\mathrm{OH}$ (phenolic) proton resonances at 11.78-12.15 ppm, imine proton resonances at $8.58-8.67 \mathrm{ppm}$ and aromatic proton resonances in the range $6.43-7.68 \mathrm{ppm}$, respectively. On coordination, the signal due to $\mathrm{OH}$ proton disappears, indicating deprotonation of the phenolic $\mathrm{OH}$ and subsequent coordination of the phenoxide oxygen to the metal atoms. Involvement of the imine nitrogen in coordination has shifted the resonance signal of the imine proton by $0.7-0.9 \mathrm{ppm}$. The peaks observed in ${ }^{13} \mathrm{C}$ NMR spectra of the Schiff bases and the complexes are in expected range and values are given in experimental section. The carbonyl $\mathrm{C}$ and imine $\mathrm{C}$ atoms in the complexes have shifted compared to their ligands, confirming the coordination through carbonyl $\mathrm{O}$ and imine $\mathrm{N}$ atoms. ${ }^{17}$

\section{4. Crystal Structure Description of the Complexes}

Complex 1 is a phenolato-bridged dinuclear zinc(II) compound (Figure 1), with $\mathrm{Zn} \cdots \mathrm{Zn}$ separation of 3.096(2) $\AA$. The crystal of the complex possesses a crystallographic inversion symmetry, with the inversion center located at the middle of the two zinc atoms. The $\mathrm{Zn}$ atom in the complex is coordinated by one pyridine $\mathrm{N}$ and two phenolate $\mathrm{O}$ atoms from two Schiff base ligands, and one I atom, generating tetrahedral geometry. The Schiff base acts as a bidentate ligand, and forms a six-membered chelate ring with the metal center through the phenolate $\mathrm{O}$ and imine $\mathrm{N}$. The bond distances subtended at the metal atoms are

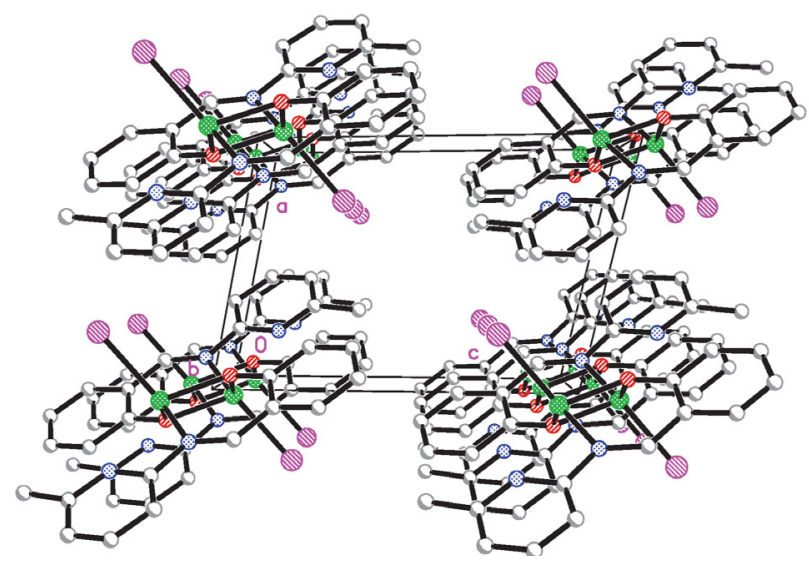

Figure 2. Molecular packing structure of complex $\mathbf{1}$. 
comparable to those observed in similar zinc(II) complexes with Schiff bases. ${ }^{18}$

In the crystal structure of the complex, molecules are stacked via $\pi \cdots \pi$ interactions (Table 3 ) along the $b$ axis (Figure 2).

Complex 2 is a thiocyanate-coordinated mononuclear zinc(II) compound (Figure 3). The $\mathrm{Zn}$ atom in the complex is coordinated by two phenolate $\mathrm{O}$ atoms from two zwitterionic Schiff base ligands, and two thiocyanate $\mathrm{N}$ atoms, generating tetrahedral geometry. The Schiff base

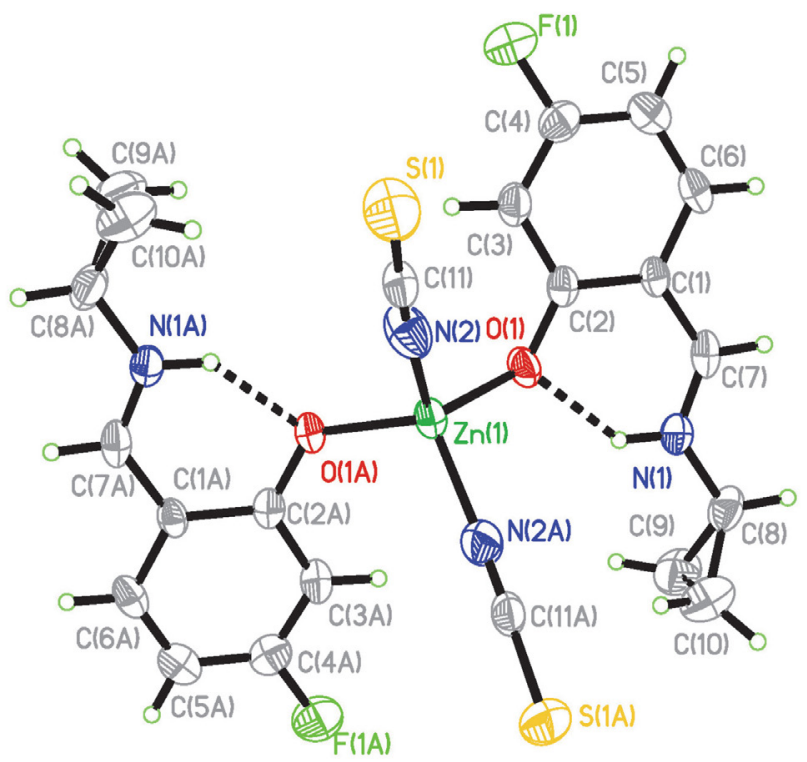

Figure 3. Molecular structure of complex 2. Atoms labeled with the suffix $\mathrm{A}$ are at the symmetry position $-x, y, 1 / 2-z$.

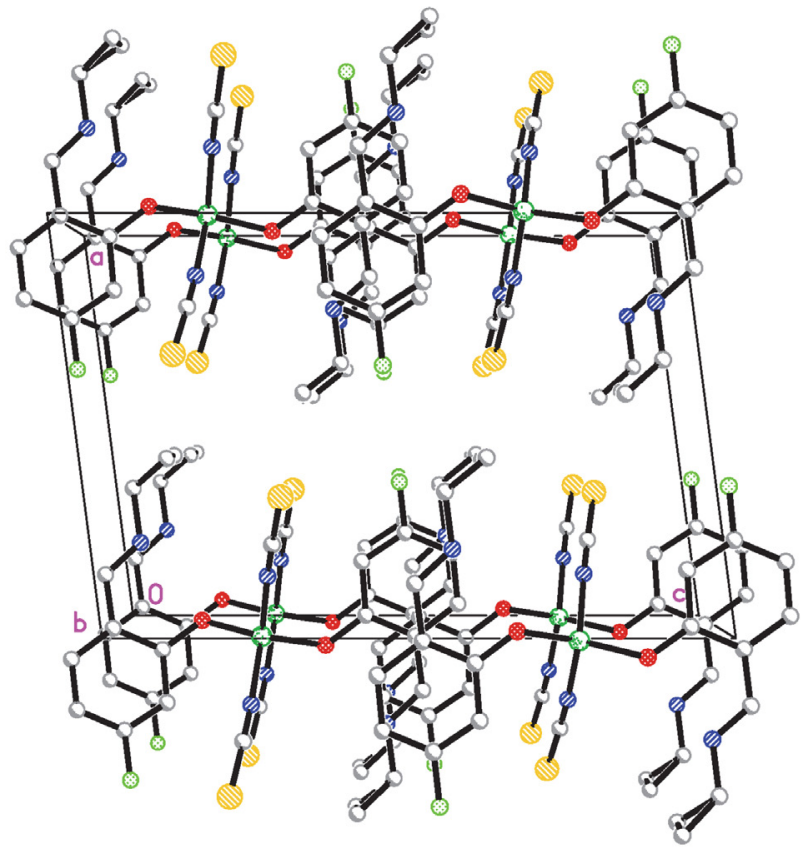

Figure 4. Molecular packing structure of complex 2. acts as a monodentate ligand, with the phenol $\mathrm{H}$ atom transferred to the imino $\mathrm{N}$ group. The bond distances subtended at the metal atoms are comparable to those observed in similar zinc(II) complexes with Schiff bases and thiocyanate ligands. ${ }^{19}$

In the crystal structure of the complex, molecules are stacked via $\pi \cdots \pi$ interactions (Table 3 ) including the pyridine ring $\mathrm{N}(2)-\mathrm{C}(8)-\mathrm{C}(12)-\mathrm{C}(11)-\mathrm{C}(10)-\mathrm{C}(9)$ and the chelate ring $\mathrm{Zn}(1)-\mathrm{N}(1)-\mathrm{C}(8)-\mathrm{N}(2)$, along the $b$ axis (Figure 4).

Complex 3 is an iodide-coordinated mononuclear zinc(II) compound (Figure 5). The $\mathrm{Zn}$ atom in the complex is coordinated by one phenolate $\mathrm{O}$, one imino $\mathrm{N}$, and one morpholine $\mathrm{N}$ atoms of the Schiff base ligand, and one I atom, generating tetrahedral geometry. The Schiff base acts as a tridentate ligand, with the morpholine ring adopts chair configuration. The bond distances subtended at the metal atoms are comparable to those observed in similar zinc(II) complexes with Schiff bases and thiocyanate ligands. ${ }^{20}$

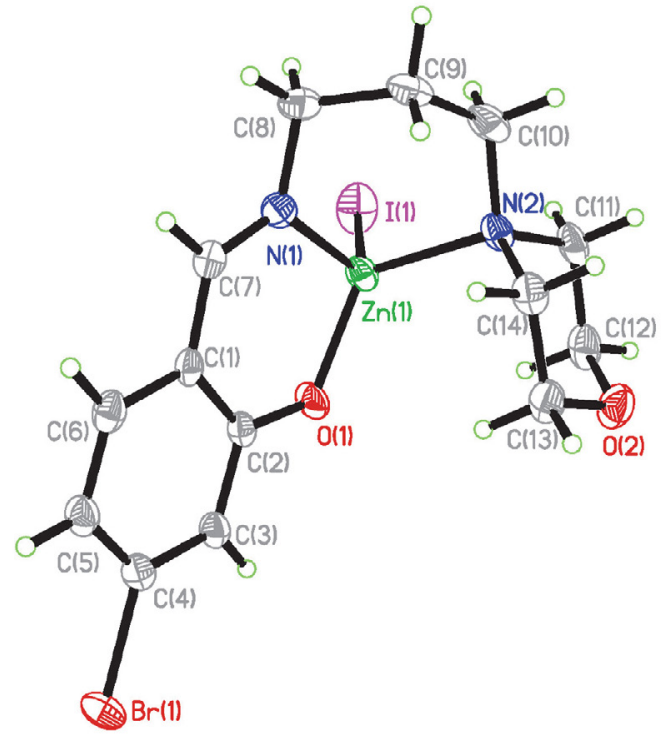

Figure 5. Molecular structure of complex 3.

In the crystal structure of the complex, molecules are stacked via $\pi \cdots \pi$ interactions (Table 3 ) including the phenyl ring $\mathrm{C}(1)-\mathrm{C}(2)-\mathrm{C}(3)-\mathrm{C}(4)-\mathrm{C}(5)-\mathrm{C}(6)$ and the chelate ring $\mathrm{Zn}(1)-\mathrm{O}(1)-\mathrm{C}(2)-\mathrm{C}(1)-\mathrm{C}(7)-\mathrm{N}(1)$, along the $b$ axis (Figure 6).

\section{5. Antimicrobial Activity}

The results of the antimicrobial activity are summarized in Table 4. A comparative study of minimum inhibitory concentration (MIC) values of the Schiff base and the zinc complex indicated that the complex has more effective activity against Staphylococcus aureus, Escherichia coli, and Candida albicans than the free Schiff base. Generally, 


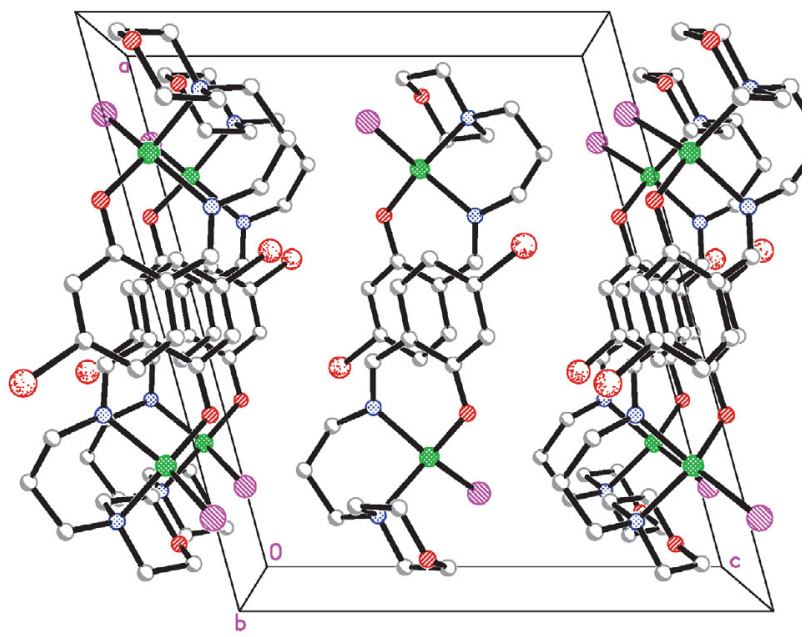

Figure 6. Molecular packing structure of complex 3. this is caused by the greater lipophilic nature of the complex than the ligand. Such increased activity of the metal chelates can be explained on the basis of chelating theory. ${ }^{21}$ On chelating, the polarity of the metal atoms will be reduced to a greater extent due to the overlap of the ligand orbital and partial sharing of positive charge of the metal atoms with donor atoms. Further, it increases the delocalization of $\pi$-electrons over the whole chelate ring and enhances the lipophilicity of the complex. This increased lipophilicity enhances the penetration of the complex into lipid membrane and blocks the metal binding sites on enzymes of micro-organisms.

The complexes have stronger activities against Staphylococcus aureus, Escherichia coli, and Candida albicans than the free Schiff bases. For Staphylococcus aureus and Escherichia coli, the activities of the complexes are less than the control drug Tetracycline. But for Candida albi-

Table 2. Selected bond distances $(\AA)$ and angles $\left(^{\circ}\right)$ for the complexes

\begin{tabular}{lrlr}
\hline $\mathbf{1}$ & & & \\
$\mathrm{Zn}(1)-\mathrm{O}(1)^{\# 1}$ & $1.990(5)$ & $\mathrm{Zn}(1)-\mathrm{O}(1)$ & $2.080(4)$ \\
$\mathrm{Zn}(1)-\mathrm{N}(1)$ & $2.014(5)$ & $\mathrm{Zn}(1)-\mathrm{I}(1)$ & $2.541(1)$ \\
$\mathrm{O}(1)-\mathrm{Zn}(1)-\mathrm{N}(1)^{\# 1}$ & $122.3(2)$ & $\mathrm{O}(1)-\mathrm{Zn}(1)-\mathrm{O}(1)^{\# 1}$ & $81.0(2)$ \\
$\mathrm{O}(1)-\mathrm{Zn}(1)-\mathrm{N}(1)$ & $88.1(2)$ & $\mathrm{O}(1)-\mathrm{Zn}(1)-\mathrm{I}(1)^{\# 1}$ & $113.3(1)$ \\
$\mathrm{N}(1)-\mathrm{Zn}(1)-\mathrm{I}(1)$ & $122.9(2)$ & $\mathrm{O}(1)-\mathrm{Zn}(1)-\mathrm{I}(1)$ & $113.1(1)$ \\
\hline $\mathbf{2}$ & & & \\
$\mathrm{Zn}(1)-\mathrm{O}(1)$ & $1.929(4)$ & $\mathrm{Zn}(1)-\mathrm{N}(2)$ & $1.958(6)$ \\
$\mathrm{O}(1)-\mathrm{Zn}(1)-\mathrm{O}(1)^{\# 2}$ & $117.1(2)$ & $\mathrm{O}(1)-\mathrm{Zn}(1)-\mathrm{N}(2)$ & $109.8(2)$ \\
$\mathrm{O}(1)-\mathrm{Zn}(1)-\mathrm{N}(2)^{\# 2}$ & $103.8(2)$ & $\mathrm{N}(2)-\mathrm{Zn}(1)-\mathrm{N}(2)^{\# 2}$ & $112.7(4)$ \\
\hline $\mathbf{3}$ & & & \\
$\mathrm{Zn}(1)-\mathrm{I}(1)$ & $2.5319(8)$ & $\mathrm{Zn}(1)-\mathrm{O}(1)$ & $1.905(4)$ \\
$\mathrm{Zn}(1)-\mathrm{N}(1)$ & $1.989(5)$ & $\mathrm{Zn}(1)-\mathrm{N}(2)$ & $2.111(4)$ \\
$\mathrm{O}(1)-\mathrm{Zn}(1)-\mathrm{N}(1)$ & $96.47(18)$ & $\mathrm{O}(1)-\mathrm{Zn}(1)-\mathrm{N}(2)$ & $120.94(19)$ \\
$\mathrm{N}(1)-\mathrm{Zn}(1)-\mathrm{N}(2)$ & $94.06(19)$ & $\mathrm{O}(1)-\mathrm{Zn}(1)-\mathrm{I}(1)$ & $116.24(13)$ \\
$\mathrm{N}(1)-\mathrm{Zn}(1)-\mathrm{I}(1)$ & $119.21(14)$ & $\mathrm{N}(2)-\mathrm{Zn}(1)-\mathrm{I}(1)$ & $107.99(12)$ \\
\hline
\end{tabular}

Symmetry codes: ${ }^{\# 1}-x, 1-y, 2-z$; $^{\# 2}-x, 1-y, 2-z$.

Table 3. Parameters between the planes for the complexes

\begin{tabular}{|c|c|c|c|c|c|c|}
\hline $\mathrm{Cg}$ & $\begin{array}{c}\text { Distance } \\
\text { between ring } \\
\text { centroids }(\AA)\end{array}$ & $\begin{array}{l}\text { Dihedral } \\
\text { angle }\left({ }^{\circ}\right)\end{array}$ & $\begin{array}{c}\text { Perpendicular } \\
\text { distance of } \mathrm{Cg}(\mathrm{I}) \\
\text { on } \mathrm{Cg}(\mathrm{J})(\AA)\end{array}$ & $\begin{array}{c}\text { Beta } \\
\text { angle }\left({ }^{\circ}\right)\end{array}$ & $\begin{array}{l}\text { Gamma } \\
\text { angle }\left({ }^{\circ}\right)\end{array}$ & $\begin{array}{c}\text { Perpendicular } \\
\text { distance of } \mathrm{Cg}(\mathrm{J}) \\
\text { on } \mathrm{Cg}(\mathrm{I})(\AA)\end{array}$ \\
\hline \multicolumn{7}{|l|}{1} \\
\hline$C g(1)-C g(2)^{\# 1}$ & 3.879 & 4.877 & 3.4456 & 32.19 & 27.34 & 3.2826 \\
\hline$C g(2)-C g(2)^{\# 1}$ & 3.657 & 0 & 3.3852 & 22.24 & 22.24 & 3.3852 \\
\hline$C g(2)-C g(3)^{\# 2}$ & 3.664 & 2.391 & -3.4737 & 18.96 & 18.56 & -3.4655 \\
\hline \multicolumn{7}{|l|}{2} \\
\hline$C g(4)-C g(4)^{\# 3}$ & 4.152 & 0 & -3.428 & 34.36 & 34.36 & -3.428 \\
\hline \multicolumn{7}{|l|}{3} \\
\hline$C g(5)-C g(6)^{\# 4}$ & 4.143 & 2.088 & -3.295 & 37.02 & 37.33 & -3.308 \\
\hline$C g(6)-C g(6)^{\# 5}$ & 4.260 & 0 & 3.654 & 30.91 & 30.91 & 3.654 \\
\hline
\end{tabular}

1: $C g(1), C g(2)$ and $C g(3)$ are the centroids of $\mathrm{Zn}(1)-\mathrm{N}(1)-\mathrm{C}(8)-\mathrm{N}(2), \mathrm{N}(2)-\mathrm{C}(8)-\mathrm{C}(12)-\mathrm{C}(11)-\mathrm{C}(10)-\mathrm{C}(9)$ and $\mathrm{C}(1)-\mathrm{C}(2)-\mathrm{C}(3)-\mathrm{C}(4)-$ $\mathrm{C}(5)-\mathrm{C}(6)$, respectively. 2: $C g(4)$ is the centroid of $\mathrm{C}(1)-\mathrm{C}(2)-\mathrm{C}(3)-\mathrm{C}(4)-\mathrm{C}(5)-\mathrm{C}(6)$. 3: $C g(5)$ and $C g(6)$ are the centroids of $\mathrm{Zn}(1)-\mathrm{O}(1)-$ $\mathrm{C}(2)-\mathrm{C}(1)-\mathrm{C}(7)-\mathrm{N}(1)$ and $\mathrm{C}(1)-\mathrm{C}(2)-\mathrm{C}(3)-\mathrm{C}(4)-\mathrm{C}(5)-\mathrm{C}(6)$, respectively. Symmetry codes: \#1: 1-x, 1-y, $-z ; \# 2: 2-x, 1-y,-z ; \# 3:-x, 1-y,-z$; $\# 4: 1-x, 1-y, 1-z ; \# 5: 1-x, 2-y, 1-z$. 
cans, the complexes have stronger activities than Tetracycline. Complex $\mathbf{2}$ has the most activity against Staphylococcus aureus with MIC value of $2 \mu \mathrm{g} / \mathrm{mL}$. The three zinc complexes have higher activities against Staphylococcus aureus and lower activities against Escherichia coli and Candida albicans than the zinc(II) and manganese(II) complexes with the ligand $N^{\prime}$-(1-(pyridin-2-yl)ethylidene)isonicotinohydrazide. ${ }^{22}$ Further work needs to be carried out to investigate the structure-activity relationship.

Table 4. MIC values $(\mu \mathrm{g} / \mathrm{mL})$ for the antimicrobial activities of the tested compounds

\begin{tabular}{lccc}
\hline Compound & $\begin{array}{c}\text { Staphylococcus } \\
\text { aureus }\end{array}$ & $\begin{array}{c}\text { Escherichia } \\
\text { coli }\end{array}$ & $\begin{array}{c}\text { Candida } \\
\text { albicans }\end{array}$ \\
\hline $\mathrm{HL}^{1}$ & 128 & 256 & $>1024$ \\
$\mathrm{HL}^{2}$ & 128 & 128 & $>1024$ \\
$\mathrm{HL}^{3}$ & 64 & 256 & $>1024$ \\
$\mathbf{1}$ & 4 & 16 & 128 \\
$\mathbf{2}$ & 2 & 32 & 256 \\
$\mathbf{3}$ & 4 & 32 & 256 \\
Tetracycline & 0.25 & 2.0 & $>1024$ \\
\hline
\end{tabular}

\section{Conclusions}

In summary, three new zinc(II) complexes with halide and pseudohalide ligands derived from Schiff bases have been prepared and characterized. The structures of the complexes are confirmed by single crystal X-ray crystallographic determination. The $\mathrm{Zn}$ atoms in the complexes are in tetrahedral coordination. The complexes have better activities on the bacteria Staphylococcus aureus and Escherichia coli than the control drug Tetracycline. Moreover, the complexes have stronger activities against Candida albicans than Tetracycline. Interestingly, complex $\mathbf{2}$ has the most activity against Staphylococcus aureus with MIC value of $2 \mu \mathrm{g} / \mathrm{mL}$.

\section{Acknowledgments}

This research was supported by the National Sciences Foundation of China (nos. 20676057 and 20877036) and Top-class foundation of Pingdingshan University (no. 2008010).

\section{References}

1. L. N. Obasi, J. C. Ezeorah, V. Ossai, A. Jude, U. S. Oruma, A. Ibezim, M. Lutter, L. Rhyman, K. Jurkschat, N. Dege, P. Ramasami, J. Mol. Struct. 2019, 1188, 69-75.

DOI:10.1016/j.molstruc.2019.03.081

2. (a) S. K. Bharti, G. Nath, R. Tilak, S. K. Singh, Eur. J. Med. Chem.
2010, 45, 651-660; DOI:10.1016/j.ejmech.2009.11.008

(b) M. Ceruso, F. Carta, S. M. Osman, Z. Alothman, S. M. Monti, C. T. Supuran, Bioorg. Med. Chem. 2015, 23, 41814187; DOI:10.1016/j.bmc.2015.06.050

(c) W. L. Wang, D. Agustin, R. Poll, Mol. Catal. 2017, 443, 52-59; DOI:10.1016/j.mcat.2017.09.033

(d) M. Hanif, M. Hassan, M. Rafiq, Q. Abbas, A. Ishaq, S. Shahzadi, S.-Y. Seo, M. Saleem, Pharm. Chem. J. 2018, 52, 424-437; DOI:10.1007/s11094-018-1835-0

(e) P. Mishra, P. N. Gupta, K. Ashok, R. Shukla, R. C. Srimal, Indian J. Physiol. Pharm. 1995, 39, 169-172.

3. (a) K. Venkateswarlu, N. Ganji, S. Daravath, K. Kanneboina, K. Rangan, Shivaraj, Polyhedron 2019, 171, 86-97;

DOI:10.1016/j.poly.2019.06.048

(b) R. A. Ammar, A. N. M. A. Alaghaz, M. E. Zayed, L. A. Al-Bedair, J. Mol. Struct. 2017, 1141, 368-381;

DOI:10.1016/j.molstruc.2017.03.080

(c) N. R. Palepu, S. L. Nongbri, J. R. Premkumar, A. K. Verma, K. Bhattacharjee, S. R. Joshi, S. Forbes, Y. Mozharivskyj, R. Thounaojam, K. Aguan, M. R. Kollipara, J. Biol. Inorg. Chem. 2015, 20, 619-638; DOI:10.1007/s00775-015-1249-3

(d) M. Aidi, H. Keypour, A. Shooshtari, M. Mahmoudabadi, M. Bayat, Z. Ahmadvand, R. Karamian, M. Asadbegy, S. Tavatli, R. W. Gable, Polyhedron 2019, 167, 93-102. DOI:10.1016/j.poly.2019.02.030

4. (a) C. X. Yuan, L. P. Lu, X. L. Gao, Y. B. Wu, M. L. Guo, Y. Li, X. Q. Fu, M. L. Zhu, J. Bio. Inorg. Chem. 2009, 14, 841-851; DOI:10.1007/s00775-009-0496-6

(b) P. A. Khalf-Alla, S. S. Hassan, M. M. Shoukry, Inorg. Chim. Acta 2019, 492, 192-197; DOI:10.1016/j.ica.2019.04.035 (c) S. Daravath, A. Rambabu, N. Vamsikrishna, N. Ganji, S. Raj, J. Coord. Chem. 2019, 72, 1973-1993;

DOI:10.1080/00958972.2019.1634263

(d) M. S. S. Adam, L. H. Abdel-Rahman, A. M. Abu-Dief, N. A. Hashem, Inorg. Nano-Met. Chem. 2019, 50, 136-150; DOI:10.1080/24701556.2019.1672735

(e) M. Sonmez, M. Celebi, I. Berber, Eur. J. Med. Chem. 2010, 45, 1935-1940; DOI:10.1016/j.ejmech.2010.01.035

(f) L. W. Xue, G. Q. Zhao, Y. J. Han, Y. X. Feng, Russ. J. Coord. Chem. 2011, 37, 262-269; DOI:10.1134/S1070328411030110 (g) L. W. Xue, Y. J. Han, G. Q. Zhao, Y. X. Feng, Russ. J. Coord. Chem. 2012, 38, 24-28. DOI:10.1134/S1070328411120104

5. (a) Q.-M. Hasi, Y. Fan, X.-X. Feng, X.-Q. Yao, J.-C. Liu, Transition Met. Chem. 2016, 41, 685-692;

DOI:10.1007/s11243-016-0069-9

(b) P. A. Khalf-Alla, S. S. Hassan, M. M. Shoukry, Inorg. Chim. Acta 2019, 492, 192-197;

DOI:10.1016/j.ica.2019.04.035

(c) S. Daravath, A. Rambabu, N. Vamsikrishna, N. Ganji, S. Raj, J. Coord. Chem. 2019, 72, 1973-1993;

DOI:10.1080/00958972.2019.1634263

(d) M. S. S. Adam, L. H. Abdel-Rahman, A. M. Abu-Dief, N. A. Hashem, Inorg. Nano-Met. Chem. 2019, 50, 136-150. DOI:10.1080/24701556.2019.1672735

6. M. Zhang, D.-M. Xian, H.-H. Li, J.-C. Zhang, Z.-L. You, Aust. J. Chem. 2012, 65, 343-350. DOI:10.1071/CH11424 
7. (a) L.-W. Xue, H.-J. Zhang, P.-P. Wang, Acta Chim. Slov. 2019, 66, 190-195;

(b) G.-X. He, L.-W. Xue, Q.-L. Peng, P.-P. Wang, H.-J. Zhang, Acta Chim. Slov. 2019, 66, 570-575;

DOI:10.17344/acsi.2018.4868

(c) L.-W. Xue, Y.-J. Han, X.-Q. Luo, Acta Chim. Slov. 2019, 66, 622-628. DOI:10.17344/acsi.2019.5039

8. (a) A. Castineiras, J. A. Castro, M. L. Duran, J. A. Garcia-Vazquez, A. Macias, J. Romero, A. Sousa, Polyhedron 1989, 8, 2543-2549; DOI:10.1016/S0277-5387(00)81154-7

(b) L. Xu, Y. V. Mironov, X. Qi, S.-J. Kim, J. Struct. Chem. 2006, 47, 998-1001. DOI:10.1007/s10947-006-0418-1

9. Bruker, SMART and SAINT, Area Detector Control and Integration Software, Madison (WI, USA): Bruker Analytical X-ray Instruments Inc., 1997.

10. G. M. Sheldrick, SADABS, Program for Empirical Absorption Correction of Area Detector Data, Göttingen (Germany): Univ. of Göttingen, 1997.

11. A. C. T. North, D. C. Phillips, F. S. Mathews, Acta Crystallogr. A 1968, 24, 351-359. DOI:10.1107/S0567739468000707

12. G. M. Sheldrick, SHELXL-97, Program for the Refinement of Crystal Structures, Göttingen (Germany): Univ. of Göttingen, 1997.

13. (a) A. Barry, Procedures and Theoretical Considerations for Testing Antimicrobial Agents in Agar Media, In: Antibiotics in Laboratory Medicine, Lorian, V., Ed., Baltimore: Williams and Wilkins, 1991;

(b) T. Rosu, M. Negoiu, S. Pasculescu, E. Pahontu, D. Poirier, A. Gulea, Eur. J. Med. Chem. 2010, 45, 774-781.

DOI:10.1016/j.ejmech.2009.10.034

14. A. Ray, D. Sadhukhan, G. M. Rosair, C. J. Gomez-Garcia, S. Mitra, Polyhedron 2009, 28, 3542-3550.

DOI:10.1016/j.poly.2009.07.017

15. S. B asak, S. Sen, S. Banerjee, S. Mitra, G. Rosair, M. T. G. Rodriguez, Polyhedron 2007, 26, 5104-5112.

DOI:10.1016/j.poly.2007.07.025
16. M. Enamullah, M. A. Quddus, M. A. Halim, M. K. Islam, V. Vasylyeva, C. Janiak, Inorg. Chim. Acta 2015, 103-111.

DOI:10.1016/j.ica.2014.11.020

17. D. S. Badiger, R. S. Hunoor, B. R. Patil, R. S. Vadavi, C. V. Mangannavar, I. S. Muchchandi, Y. P. Patil, M. Nethaji, K. B. Gudasi, Inorg. Chim. Acta 2012, 197-203.

DOI:10.1016/j.ica.2011.11.063

18. (a) F.-W. Wang, Y.-J. Wei, Q.-Y. Zhu, Chin. J. Struct. Chem. 2007, 26, 1327-1331;

(b) Z.-L. You, X. Han, J. Wang, J.-Y. Chi, Chin. J. Struct. Chem. 2006, 25, 1043-1046;

(c) T. Chattopadhyay, M. Mukherjee, K. S. Banu, A. Banerjee, E. Suresh, E. Zangrando, D. Das, J. Coord. Chem. 2009, 62, 967-979; DOI:10.1080/00958970802385837

(d) A. Guha, T. Chattopadhyay, N. D. Paul, M. Mukherjee, S. Goswami, T. K. Mondal, E. Zangrando, D. Das, Inorg. Chem. 2012, 51, 8750-8759; DOI:10.1021/ic300400v

(e) J. Qin, Y. Sun, Z. N. Xia, Y. Zhang X. L. Zhao, Z. L. You, H. L. Zhu, Russ. J. Coord. Chem. 2016, 42, 330-337. DOI:10.1134/S1070328416050055

19. (a) N. Wang, L. Chen, L. Yang, Y. Wan, Synth. React. Inorg. Met.-Org. Nano-Met. Chem. 2014, 44, 315-319;

DOI:10.1080/15533174.2013.770763

(b) D.-H. Shi, Z.-L. Cao, W.-W. Liu, R.-B. Xu, L.-L. Gao, Q. Zhang, Synth. React. Inorg. Met.-Org. Nano-Met. Chem. 2012, 42, 864-867. DOI:10.1080/15533174.2011.618483

20. (a) J.-N. Li, Synth. React. Inorg. Met.-Org. Nano-Met. Chem. 2013, 43, 832-837;

(b) S. S. Qian, X. S. Cheng, J. Q. Ren, Z. L. You, H. L. Zhu, Russ. J. Coord. Chem. 2013, 39, 836-843.

DOI:10.1134/S1070328413110080

21. J. W. Searl, R. C. Smith, S. Wyard, J. Proc. Phys. Soc. 1961, 78, 1174-1178. DOI:10.1088/0370-1328/78/6/311

22. L.-W. Xue, H.-J. Zhang, P.-P. Wang, Acta Chim. Slov. 2019, 66, 190-195.

\section{Povzetek}

Trije novi cinkovi (II) kompleksi, $\left[\mathrm{Zn}_{2} \mathrm{I}_{2}\left(\mathrm{~L}^{1}\right)_{2}\right](\mathbf{1}),\left[\mathrm{Zn}\left(\mathrm{HL}^{2}\right)_{2}(\mathrm{NCS})_{2}\right]$ (2) in $\left[\mathrm{ZnIL}^{3}\right]$ (3), kjer je $\mathrm{L}^{1}$ anionska oblika 2-[(6-metilpiridin-2-ilimino)metil]fenola $\left(\mathrm{HL}^{1}\right), \mathrm{HL}^{2}$ je zwitterionska oblika 2-(ciklopropiliminometil)-5-fluorofenola $\left(\mathrm{HL}^{2}\right)$ in $\mathrm{L}^{3}$ je anionska oblika 5-bromo-2-[(3-morfolin-4-ilpropilimino)metil]fenol $\left(\mathrm{HL}^{3}\right)$, so bili pripravljeni in karakterizirani z elementno analizo, IR, UV in NMR spektroskopijo ter rentgensko difrakcijo na monokristalih. Kompleks 1 je dvojedrni cinkov kompleks, kompleksa 2 in 3 pa sta enojedrna cinkova kompleksa. Atomi Zn v kompleksih so v tetraedrski koordinaciji. Preučevana je bila tudi protimikrobna aktivnost kompleksov proti Staphylococcus aureus, Escherichia coli in Candida albicans.

Except when otherwise noted, articles in this journal are published under the terms and conditions of the Creative Commons Attribution 4.0 International License 